\title{
TREN CURAH HUJAN DAN SUHU UDARA EKSTRIM MASA DEPAN (PERIODE 2021-2030) BERDASARKAN REPRESENTATIVE CONCENTRATION PATHWAY (RCP) 4.5 DI KOTA PALU
}

\author{
PRESLI PANUSUNAN SIMANJUNTAK, AGUS SAFRIL \\ Prodi Klimatologi, \\ Sekolah Tinggi Meteorologi Klimatologi dan Geofisika Jl. Perhubungan 1 No. 5 \\ Pondok Betung, Pondok Aren Bintaro - Tangerang Selatan 15221 \\ *email : preslisimanjuntak06@gmail.com
}

\begin{abstract}
Abstrak. Penelitian tentang perubahan iklim secara global yang dilakukan oleh IPCC menunjukan bahwa frekuensi dan intensitas kejadian iklim ekstrim cendrung semakin meningkat. Perubahan sifat iklim ekstrim akan memberikan dampak yang besar pada berbagai sektor, diantaranya sektor pertanian, perikanan, maritim, infrastruktur dan lainnya. Penelitian ini menggunakan skenario RCP 4.5 sebagai skenario perubahaan iklim masa mendatang untuk mengetahui trend indeks suhu dan hujan ekstrim periode 2021 2030 di Kota Palu. Data suhu udara dan curah hujan hasil proyeksi diolah menggunakan SoftwareRClimDex sehingga didapatkan data indeks suhu dan hujan ekstrim masa mendatang. Indeks-indeks tersebut merupakan indeks iklim ekstrim yang ditetapkan oleh ETCCDMI yang terdiri atas TN10p, TN90p, TX10p, TX90p, TNn, TNx, TXn, TXx,DTR, RX1day, RX5day, PRCPTOT, CDD, CWD dan R95p. Hasil menunjukkan bahwa frekuensi kejadian rata-rata suhu maksimum dan minimum meningkat setiap tahun. Frekuensi kejadian rata-rata suhu panas dimalam hari dan dingin dimala hari mengalami peningkatan. Sedangkan rekuensi kejadian rata-rata suhu dingin disiang hari mengalami penurunan tetapi panas disiang hari mengalami peningkatan. Tren meningkat juga terjadi pada kejadian curah hujan ekstrim (diatas persentil 95\%) dan total curah hujan tahunan meningkat. Peningkatan frekuensi kejadian cuaca/iklim ekstrim dapat menyebabkan semakin tingginya potensi bencana hidrometeorologi dimasa depan.
\end{abstract}

Kata kunci: indeks iklim ekstrim, hujan ekstrim, suhu ekstrim

\begin{abstract}
Research on global climate change carried out by the IPCC shows that the frequency and intensity of extreme climate events tends to increase. Changes in the nature of extreme climates will have a major impact on various sectors, including agriculture, fisheries, maritime, infrastructure and others. This study uses the RCP 4.5 scenario as a scenario for future climate change to determine the trend of extreme temperature and rain indices for the period 2021-2030 in Palu. The temperature and rainfall data from the projections are processed using SoftwareRClimDex so that future temperature index and extreme rain data can be obtained. These indices are the extreme climate indices established by the ETCCDMI which consist of TN10p, TN90p, TX10p, TX90p, TNn, TNx, TXn, TXx, DTR, RX1day, RX5day, PRCPTOT, CDD, CWD and R95p. The results show that the average frequency of maximum and minimum temperatures increases every year. The frequency of events on average at night and cold at night has increased. While the average incidence of cold temperatures during the day has decreased but and the heat during the day has increased. The increasing trend also occurs in extreme rainfall events (above the $95 \%$ percentile) and total annual rainfall. Increasing the frequency of extreme weather / climate events can lead to higher potential for hydrometeorological disasters in the future.
\end{abstract}

Keywords: extreme climate index, extreme rain, extreme temperatures

JIIF (Jurnal Ilmu dan Inovasi Fisika), ISSN: 2549-0516 


\section{Pendahuluan}

Perubahan iklim merupakan perubahan rata-rata atau variabilitas unsur-unsur iklim yang terjadi dalam waktu yang panjang dan berkelanjutan. Berlangsungya perubahan pola iklim ini telah terjadi sejak dimulainya revolusi indusrti 1.0 tahun 1750. Revolusi industri yang terjadi mendorong terjadinya peningkatan konsentrasi gas-gas rumah kaca di atmosfer. Gas-gas rumah kaca ini menyebabkan pantulan radiasi gelombang panjang dari bumi ke atmosfer menjadi terperangkap di lapisan atmosfer sehingga menyebabkan terjadinya peningkatan temperatur permukaan bumi atau disebut sebagai pemanasan global. Terjadinya pemanasan global mengakibatkan adanya perubahan sistem iklim. Perubahan yang terjadi dalam sistem iklim mendorong adanya perubahan intensitas, durasi, waktu, luasan area, dan frekuensi muculnya kejadian cuaca ekstrim dan iklim ekstrim. Kejadian cuaca ekstrim dan iklim ekstrim merupakan bagian dari variabilitas sistem iklim baik dalam kondisi stabil ataupun terjadi perubahan iklim. Kejadian tersebut didefinisikan sebagai suatu nilai dari variabel cuaca atau iklim yang berada di atas atau di bawah nilai ambang batas kisaran nilai variabel yang diamati [1].

Kejadian cuaca ekstrim dan iklim ekstrim yang terjadi meliputi presipitasi yang ekstrim, baik dalam bentuk hujan, hujan es dan salju. Tidak adanya hujan dalam jangka waktu tertentu dengan penguapan yang tinggi merupakan contoh kejadian iklim ekstrim yang menimbulkan terjadinya kekeringan. Angin permukaan yang ekstrim diasosiasikan dengan sirkulasi badai. Tiap jenis badai/storm, termasuk siklon tropis, siklon ekstratropis dan thunderstorm memiliki ukuran, kecepatan dan intensitas masing-masing. Sebuah storm yang intens dapat menyebabkan terjadinya angin berkecapatan tinggi dan hujan ekstrim. Temperatur udara yang meningkat sebagai akibat dari meningkatnya gas rumah kaca diikuti dengan berkurangnya tutupan lahan menimbulkan kejadian suhu ekstrim yang meningkat [2].

IPCC (Intergovermental Panel on Climate Change) telah menyusun beberapa skenario iklim untuk mengetahui proyeksi iklim global dan regional hingga tahun 2100. Skenario iklim merupakan representasi logis mengenai perkembangan masa depan yang koheren dan konsisten terhadap asumsi gas rumah kaca yang akan datang. IPCC sejauh ini telah mengeluarkan 5 buah laporan penilaian (Assignment Report). Dalam laporan penilaian ke-lima, IPCC menggunakan skenario yang disebut dengan Representative Concentration Pathways (RCP) yang menggambarkan radiative forcing yang akan diterima oleh bumi. Radiative forcing (RF) adalah ukuran perubahan bersih dalam keseimbangan energi dari sistem bumi dalam menanggapi beberapa gangguan eksternal dalam satuan watt permeter persegi $\left(\mathrm{Wm}^{-2}\right)$.

Saat ini telah diamati adanya perubahan secara global pada variabel iklim ekstrim. Peningkatan konsentrasi gas rumah kaca akibat aktivitas antropogenik mendorong terjadinya perubahan frekuensi kejadian cauca dan iklim ekstrim. Di beberapa wilayah, kejadian temperatur dan hujan ekstrim meningkat dibandingkan dengan nilai rata-ratanya. Kejadian iklim ekstrim, seperti gelombang panas (heat waves), banjir dan kekeringan, dapat memberikan dampak yang kuat pada masyarakat dan ekosistem. Peningkatan kejadian cuaca atau iklim ekstrim mendorong dikembangkannya penelitian untuk melakukan analisa terhadap kejadian cuaca atau iklim ekstrim. Expert Team for Climate Change Detection Monitoring and Indices (ETCCDMI) telah memfasilitasi penentuan indeks iklim ekstrim berdasarkan data harian temperatur dan hujan. Terdapat 27 indeks iklim ekstrim yang ditetapkan oleh ETCCDMI. Salah satu perangkat lunak yang banyak digunakan untuk memantau 
perubahan kondisi ekstrim dengan pendekatan penghitungan indeks iklim ekstrim yang direkomendasikan oleh ETCCDMI adalah Rclimdex [5].

Pada penelitian ini digunakan RCP 4.5 untuk proyeksi suhu dan curah hujan ekstrim di wilayah Palu untuk periode 2021-2030. RCP 4.5 merupakan proyeksi iklim dengan skenario ada upaya manusia untuk mengurangi emisi gas rumah kaca. Tren proyeksi temperatur dan hujan ekstrim di Palu untuk periode 2021-2030 dikaji berdasarkan indeks-indeks iklim ekstrim yang ditetapkan oleh ETCCDMI. Kajian ini bertujuan untuk mengetahui perubahan-perubahan yang terjadi pada temperatur dan curah hujan di Palu, Sulawesi Tengah dalam kaitannya dengan isu perubahan iklim. Untuk menentukan indeks-indeks tersebut digunakan software RclimDex.

\section{Metode Penelitian}

Data yang digunakan adalah data Representative Concentration Pathways (RCP) 4.5 dan periode Januari 2021 hingga Desember 2030 untuk pembuatan proyeksi suhu dan curah hujan ekstrim yang bersumber dari (http://cordex-ea.climate.go.kr/). Data diolah dengan menggunakan software RClimDex untuk menentukan indeks kondisi iklim yang ditetapkan oleh ETCCDMI (Expert Team for Climate Change Detection Monitoring and Indices).

RClimdex adalah program yang dijalankan dalam software $\mathrm{R}$ untuk perhitungan indeks-indeks iklim. Selanjutnya akan dianalisis menggunakan metode tren yaitu arah pergerakan time series dalam jangka panjang, yang dapat naik ataupun turun. Selain itu untuk mengetahui bagaimana pola bulanan masingmasing data digunakan metode rata-rata. Tabel 1 menampilkan daftar indeks suhu dan curah hujan ekstrim yang digunakan didalam penelitian ini.

Tabel 1. Daftar Indeks temperatur dan hujan ekstrim

\begin{tabular}{|c|c|c|c|}
\hline Indeks & $\begin{array}{c}\text { Nama } \\
\text { Indikator }\end{array}$ & Definisi & Satuan \\
\hline TN10p & Cool nights & $\begin{array}{l}\text { Persentase jumlah hari dengan temperatur minimum }<\text { persentil ke } \\
10\end{array}$ & $\%$ \\
\hline TN90p & Warm nights & $\begin{array}{l}\text { Persentase jumlah hari dengan temperatur minimum > persentil ke - } \\
90\end{array}$ & $\%$ \\
\hline TX10p & Cool days & $\begin{array}{l}\text { Persentase jumlah hari dengan temperatur maksimum }<\text { persentil ke } \\
-10\end{array}$ & $\%$ \\
\hline TX90p & Warm days & $\begin{array}{l}\text { Persentase jumlah hari dengan temperatur maksimum > persentil ke } \\
-90\end{array}$ & $\%$ \\
\hline TNn & Min Tmin & Nilai minimum bulanan dari temperatur minimum & ${ }^{\circ} \mathrm{C}$ \\
\hline TNx & Max Tmin & Nilai maksimum bulanan dari temperatur minimum & ${ }^{\circ} \mathrm{C}$ \\
\hline TXn & Min Tmax & Nilai minimum bulanan dari temperatur maksimum & ¿C \\
\hline TXx & Max Tmax & Nilai maksimum bulanan dari temperatur maksimum & ${ }^{\circ} \mathrm{C}$ \\
\hline DTR & $\begin{array}{l}\text { Diurnal } \\
\text { Temperatur }\end{array}$ & Rata-rata bulanan selisih temperatur maksimum dan minimum & ${ }^{\circ} \mathrm{C}$ \\
\hline & Range & & \\
\hline RX1day & Max-1 day & Jumlah curah hujan harian tertinggi dalam satu bulan & $\mathrm{mm}$ \\
\hline & $\begin{array}{l}\text { precipitation } \\
\text { amount }\end{array}$ & & \\
\hline RX5 day & Max-5 day & Jumlah curah hujan terbanyak selama 5 hari berturut-turut & $\mathrm{mm}$ \\
\hline & $\begin{array}{l}\text { precipitation } \\
\text { amount }\end{array}$ & & \\
\hline
\end{tabular}




\begin{tabular}{|c|c|l|c|}
\hline PRCPTOT & $\begin{array}{c}\text { Annual total wet } \\
\text { day }\end{array}$ & Jumlah curah hujan tahunan pada saat curah hujan1 mm & mm \\
\hline precipitation & $\begin{array}{c}\text { Consecutive dry } \\
\text { days }\end{array}$ & Jumlah hari terbanyak ketika curah hujan <1mm & hari \\
\hline CDD & $\begin{array}{c}\text { Consecutive wet } \\
\text { days }\end{array}$ & Jumlah hari terbanyak ketika curah hujan1mm & hari \\
\hline CWD & $\begin{array}{l}\text { Total jumlah curah hujan tahunan ketika curah hujan }>\text { persentil ke- } \\
95\end{array}$ & mm \\
\hline R95p & Very wet days & \\
\hline & & & \\
\hline
\end{tabular}

\section{Hasil dan Pembahasan}

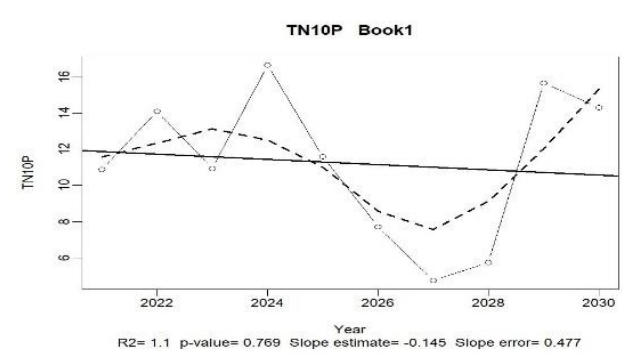

TNN Book1

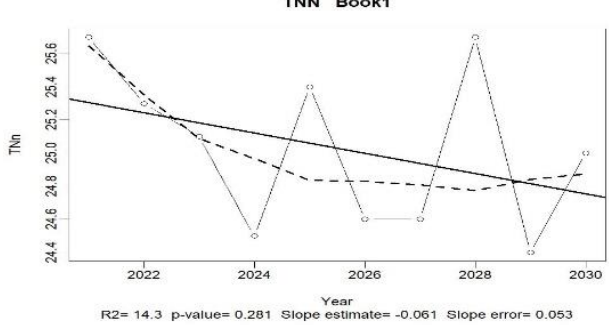

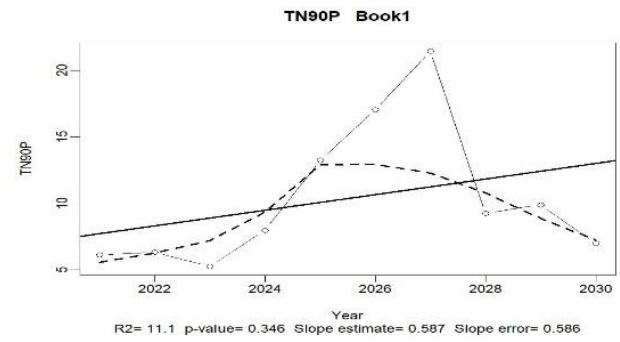

TNX Book1

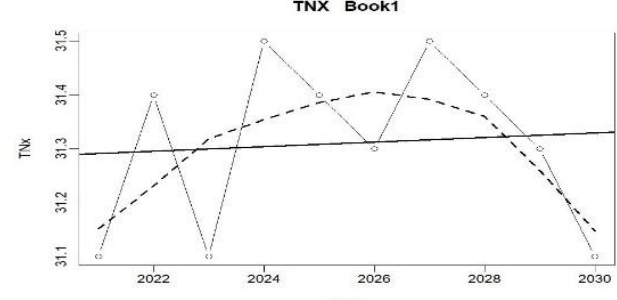

$R 2=0.6$-value $=0.825$ slope estimate $=0.004$ slope error $=0.010$

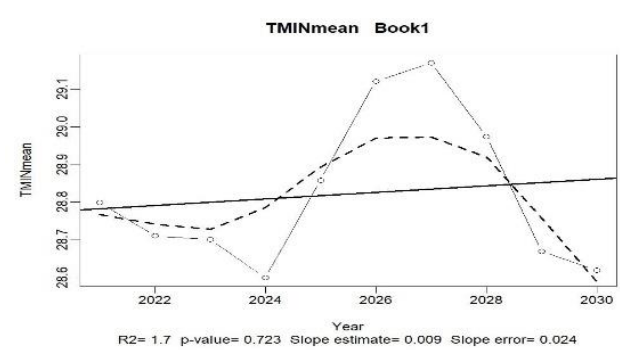

Gambar 1. Indeks Temperatur Ekstrim Berdasarkan Temperatur Minimum 2021-2030

Berdasarkan Gambar 1 dapat dilihat bahwa suhu minimum rata-rata diproyeksikan meningkat selama periode 2021-2030 dengan nilai slope kenaikan 0,009. Hasil proyeksi menunjukkan suhu minimum rata-rata tertinggi akan terjadi pada 2027 dengan nilai rata-rata $29,17^{\circ} \mathrm{C}$ sedangkan suhu maksimum terendah adalah pada 2024 dengan nilai rata-rata $28,6^{\circ} \mathrm{C}$.

Berdasarkan Gambar 1 dapat diketahui bahwa TN10p cenderung mengalami penurunan selama periode 2021 hingga 2030 dengan nilai slope sebesar $-0,145$. Persentase jumlah hari dengan temperatur minimum terkecil di proyeksikan terjadi pada tahun 2027 sebesar 4,74\% dan Persentase jumlah hari dengan temperatur minimum terbesar di proyeksikan terjadi pada tahun 2024 sebesar 16,65\%. Dengan rata-rata persentase jumlah hari dengan temperatur minimum periode 2021-2030 sebesar $11,23 \%$. 
Sementara indeks TN10p memiliki kecenderungan menurun, indeks TN90p diproyeksikan cenderung meningkat selama periode 2021 hingga 2030 dengan nilai slope 0,587 (gambar 1). Indeks TN90p atau malam hari yang panas (warm nights) didefinisikan sebagai persentase jumlah hari yang memiliki temperatur minimum di atas persentil ke 90. Nilai terendah TN90p diproyeksikan terjadi pada tahun 2023 sebesar 5,26\%, sedangkan nilai tertinggi sebesar 21,47\% terjadi pada tahun 2027 .

Pada Gambar 1 juga ditampilkan grafik indeks nilai minimum dari temperatur minimum (TNn) dan nilai maksimum dari temperatur minimum (TNx). You et al [9] menyebut TNn dan TNx sebagai temperatur terdingin di malam hari (coldest night) dan temperatur terpanas di malam hari (warmest night). Grafik TNn menunjukkan bahwa nilai minimum tahunan dari temperatur minimum memiliki tren menurun dengan nilai slope -0,061 sedangkan Grafik TNx menunjukkan bahwa nilai maksimum tahunan dari temperature minimum memiliki tren meningkat dengan nilai slope 0,004 .

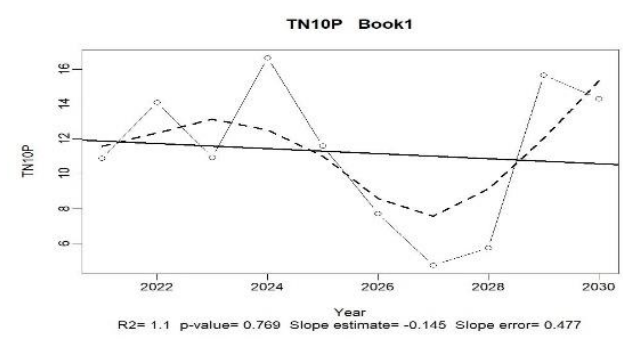

TNN Book1

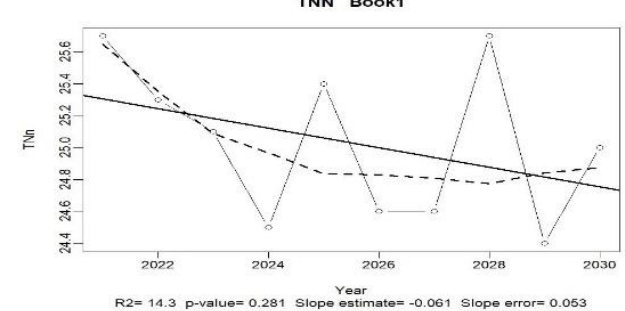

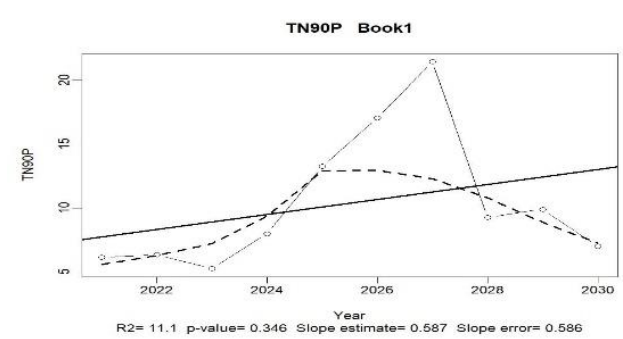

TNX Book1

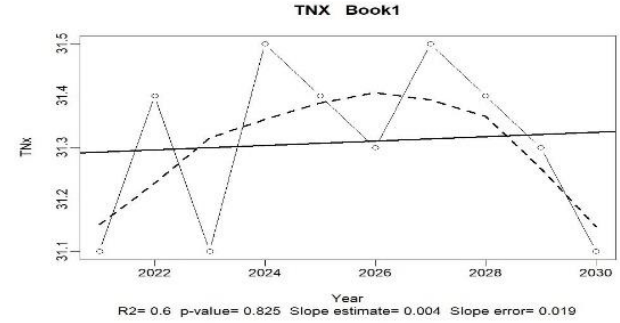

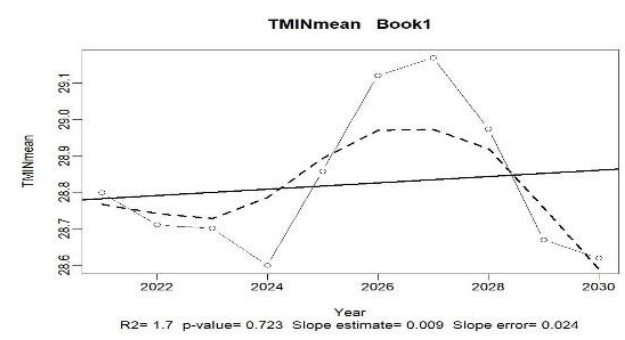

Gambar 2. Indeks Temperatur Ekstrim Berdasarkan Temperatur Maksimum 2021-2030

Berdasarkan Gambar 2 dapat dilihat bahwa suhu maksimum rata-rata cenderung meningkat selama periode 2021-2030 dengan nilai slope kenaikan 0,028. Diproyeksikaan suhu maksimum tertinggi akan terjadi pada 2027 dengan nilai ratarata $30,95{ }^{\circ} \mathrm{C}$ sedangkan suhu maksimum terendah adalah pada 2030 dengan nilai $30,51^{\circ} \mathrm{C}$. Persentase jumlah hari di mana temperatur maksimumnya lebih kecil dari persentil ke 10 dinyatakan dengan indeks TX10p atau siang hari yang dingin (cool days). Gambar 2 menunjukkan bahwa indeks TX10p hasil proyeksi mengalami penurunan periode 2021-2030 dengan nilai slope sebesar -0,084. Nilai TX10p 
tertinggi terjadi pada tahun 2024 sebesar 18,63\%, sedangkan nilai terendahnya sebesar 3,28\% pada tahun 2027.

Pada Gambar 2 juga ditampilkan grafik indeks TX90p. Indeks TX90p adalah siang hari yang panas (warm days) yang didefinisikan sebagai persentase jumlah hari dalam satu tahun dengan nilai temperatur maksimum lebih besar dari nilai persentil ke 90. Berdasarkan gambar 2 dapat diketahui bahwa indeks TX90p cenderung mengalami peningkatan sejak tahun 2021 hingga 2030 dan didapatkan nilai slope sebesar 1,043. Nilai TX90p tertinggi terjadi pada tahun 2027 sebesar 16,05\% dan terendah pada tahun 2023 sebesar $4,02 \%$.

Indeks TXn adalah indeks yang mewakili nilai minimum dari temperatur maksimum, sedangkan TXx mewakili nilai maksimum dari temperatur maksimum. Menurut You et al [9], TXn disebut sebagai temperatur terdingin di siang hari (coldest days) dan TXx disebut sebagai temperatur terpanas di siang hari (warmest days). Grafik indeks TXn menunjukkan bahwa nilai minimum dari temperatur maksimum memiliki tren meningkat dengan nilai slope 0,11 sedangkan grafik indeks TXx menunjukkan bahwa nilai maksimum dari temperatur maksimum memiliki tren meningkat dengan nilai slope 0,014 .

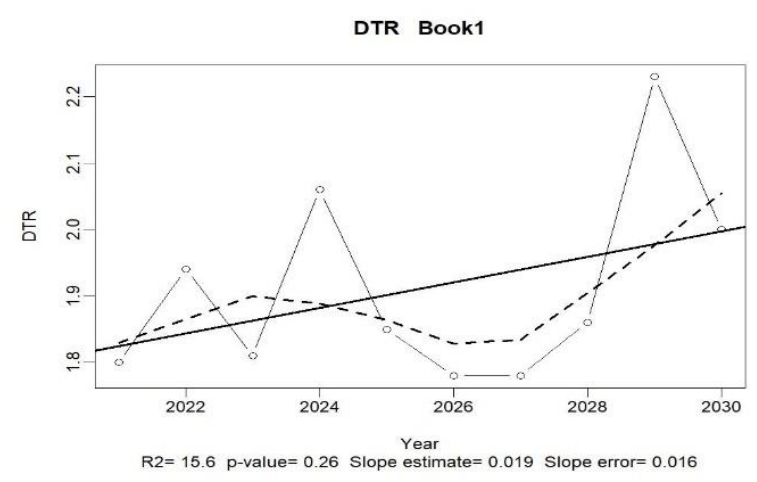

Gambar 3. Selisih Temperatur Maksimum dan Temperatur Minimum (DTR) pada periode 2021-2030

Diurnal Temperatur Range (DTR) merupakan rata-rata bulanan selisih antara temperatur maksimum dan temperatur minimum. Hasil proyeksi menunjukkan DTR cenderung mengalami peningkatan selama periode 2021-2030 (Gambar 3) dengan slope sebesar 0,016 . Hasil proyeksi menunjukkan pada tahun 2029 , tercatat nilai rata-rata DTR tertinggi sebesar $2,23^{\circ} \mathrm{C}$ dan pada tahun 2026 dan 2027 , ratarata DTR mencapai nilai terendah sebesar $1,78^{\circ} \mathrm{C}$.

Jumlah curah hujan maksimal dalam satu hari dinyatakan dengan indeks RX1day seperti yang ditampilkan pada gambar 4. Pada Gambar 4 dapat dilihat bahwa hasil proyeksi untuk kurun waktu tahun 2021-2030, curah hujan terbesar dalam satu hari memiliki kecenderungan meningkat dengan nilai slope yang relatif rendah sebesar 0,43 . Rata-rata curah hujan tertinggi dalam satu hari diproyeksikan akan terjadi pada tahun 2030 dengan curah hujan sebesar 38,7 mm/hari.

Indeks RX5day (Gambar 5) mewakili jumlah curah hujan tertinggi yang terukur dalam lima hari berturut-turut. Hasil proyeksi menunjukkan indeks ini memiliki 
kecenderungan menurun selama periode 2021-2030 dengan slope -0,872. Rata-rata curah hujan tertinggi dalam lima hari diproyeksikan akan terjadi pada tahun 2030 dengan curah hujan sebesar 106,5 mm dalam kurun waktu 5 hari.

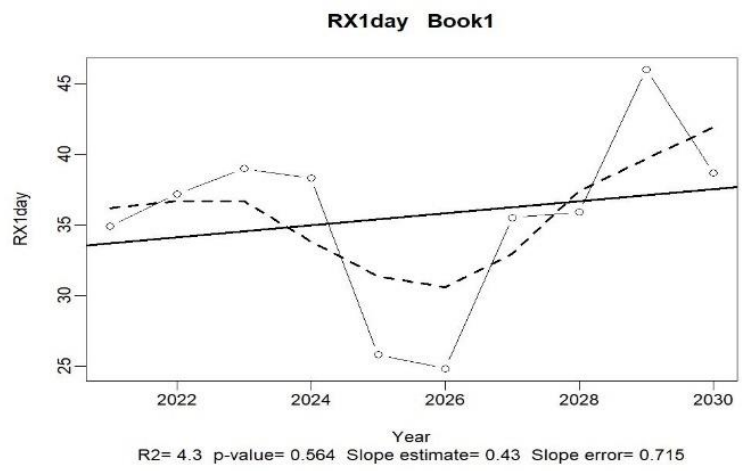

Gambar 4. Jumlah Curah Hujan Maksimum Dalam Satu Hari Periode 2021-2030

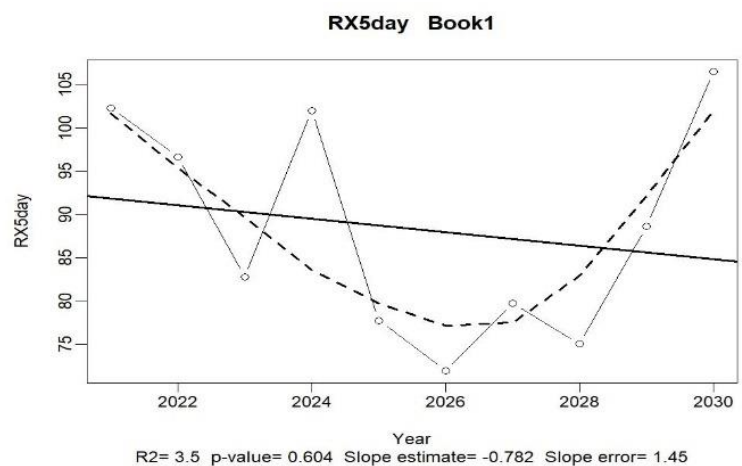

Gambar 5. Jumlah Curah Hujan Maksimum Dalam Lima Hari Berurut-turut Periode 20212030

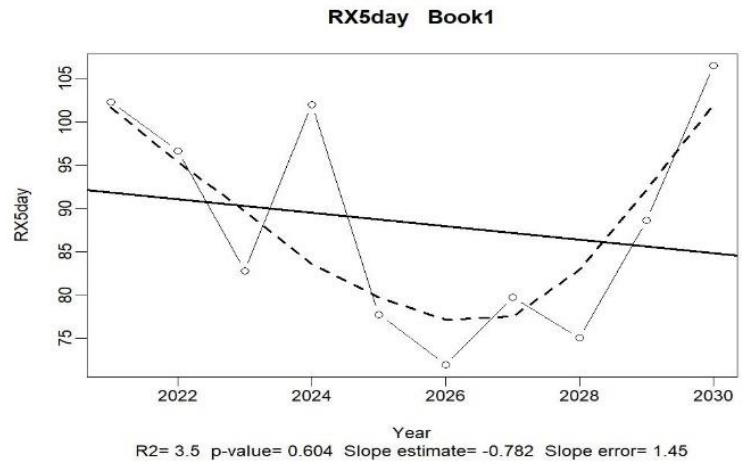

Gambar 6. Jumlah Curah Hujan Dalam Satu Tahun Periode 2021-2030

Pada Gambar 6 ditampilkan proyeksi jumlah curah hujan dalam satu tahun yang diwakili oleh indeks Annual total wet day precipitation (PRCPTOT). Proyeksi jumlah curah hujan tahunan di Stasiun Meteorologi Mutiara Palu selama tahun 2021 hingga 2030 cenderung meningkat dengan slope 33,4. Berdasarkan hasil proyeksi 
menunjukkan jumlah curah hujan terendah tercatat pada tahun 2026 sebesar 1731,5 mm, sedangkan jumlah curah hujan tertinggi tercatat pada tahun 2030 sebesar $2343,4 \mathrm{~mm}$.

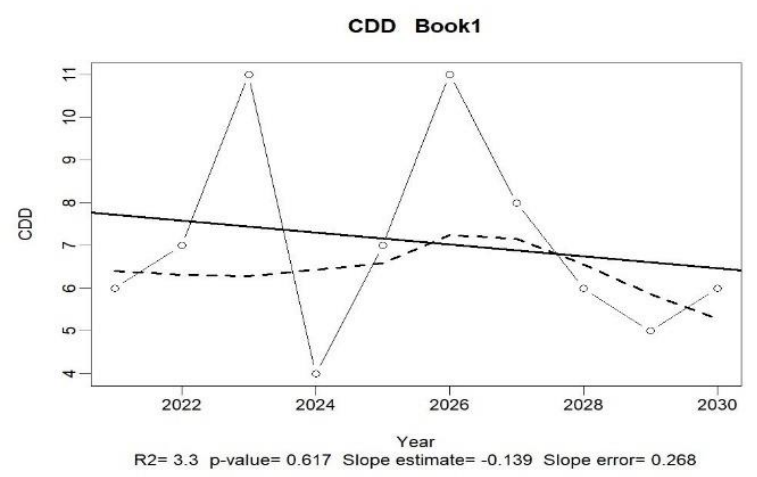

Gambar 7. Jumlah Hari Terbanyak Dalam Satu Tahun Dengan Jumlah Curah Hujan $<1 \mathrm{~mm}$ Secara Berturut-Turut

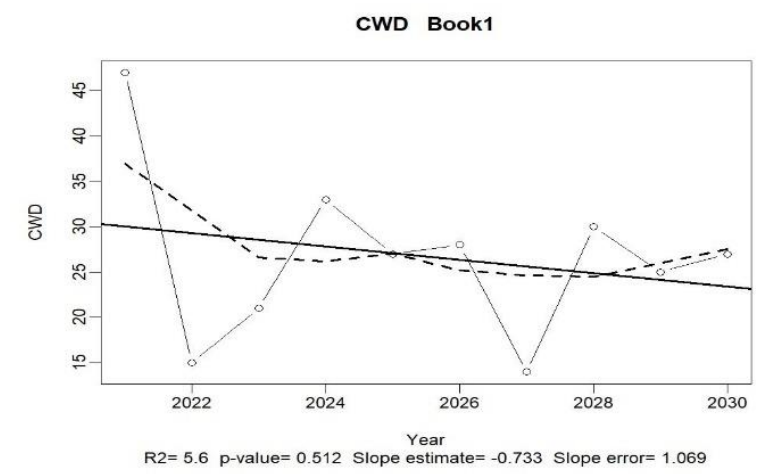

Gambar 8. Jumlah Hari Terbanyak Dalam Satu Tahun Dengan Jumlah Curah Hujan $\geq 1$ Secara Berturut-turut

Consecutive Dry Days (CDD) adalah indeks jumlah hari terbanyak dalam satu tahun dengan jumlah curah hujan $<1 \mathrm{~mm}$ secara berturut-turut. CDD juga disebut sebagai hari tanpa hujan berturut-turut [10]. Berdasarkan Gambar 7, dapat diketahui bahwa hasil proyeksi menunjukkan indeks CDD pada periode 2021-2030 di kota Palu memiliki tren menurun dengan nilai slope -0,139. Indeks CDD tertinggi terjadi pada tahun 2023 dan 2026 sebanyak 11 hari, sedangkan yang terendah terjadi pada tahun 2024 sebanyak 4 hari.

Jumlah hari maksimum dalam satu tahun dengan jumlah curah hujan $\geq 1 \mathrm{~mm}$ dinyatakan dengan indeks Consecutive Wet Days (CWD). Indeks CWD disebut juga sebagai hari hujan berturut-turut [10]. Sama halnya dengan halnya dengan indeks CDD, indeks CWD hasil proyeksi juga memiliki tren menurun selama periode 2021-2030 di Palu dengan nilai slope sebesar -0,733. Nilai CWD tertinggi terjadi pada tahun 2021 yaitu 47 hari dan yang terendah terjadi pada tahun 2027 , sebanyak 14 hari. 


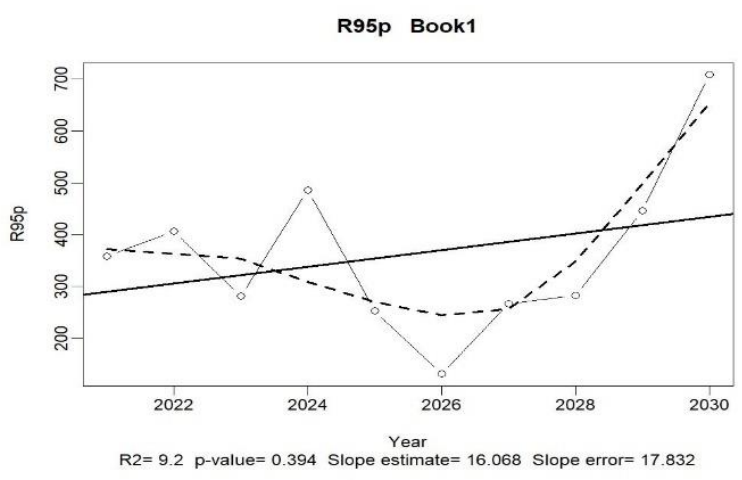

Gambar 9. Jumlah curah hujan tahunan di mana curah hujan lebih besar dari pada persentil ke95

Hari sangat basah (very wet days) atau jumlah curah hujan tahunan di mana curah hujan lebih besar daripada persentil ke 95 diwakili oleh indeks R95p (Gambar 9). Berdasarkan hasil proyeksi bahwa indeks R95p tahun 2021-2030 memiliki kecenderungan mengalami peningkatan dengan slope 16,068. Nilai curah hujan ekstrim (diatas persentil 95) tertinggi diproyeksikan akan terjadi pada tahun 2030 dengan curah hujan tertinggi sebesar $708,7 \mathrm{~mm}$, sedangkan yang terendah terjadi pada tahun 2026 sebesar 131,9 mm. Nilai indeks R95p memiliki fluktuasi yang semakin tajam sejak tahun 2027.

Berdasarkan Gambar 2 dapat dilihat bahwa suhu maksimum rata-rata cenderung meningkat selama periode 2021-2030 dengan nilai slope kenaikan 0,028. Diproyeksikaan suhu maksimum tertinggi akan terjadi pada 2027 dengan nilai ratarata $30,95^{\circ} \mathrm{C}$ sedangkan suhu maksimum terendah adalah pada 2030 dengan nilai $30,51^{\circ} \mathrm{C}$. Persentase jumlah hari di mana temperatur maksimumnya lebih kecil dari persentil ke 10 dinyatakan dengan indeks TX10p atau siang hari yang dingin (cool days). Gambar 2 menunjukkan bahwa indeks TX10p hasil proyeksi mengalami penurunan periode 2021-2030 dengan nilai slope sebesar -0,084. Nilai TX10p tertinggi terjadi pada tahun 2024 sebesar $18,63 \%$, sedangkan nilai terendahnya sebesar 3,28\% pada tahun 2027.

Pada Gambar 2 juga ditampilkan grafik indeks TX90p. Indeks TX90p adalah siang hari yang panas (warm days) yang didefinisikan sebagai persentase jumlah hari dalam satu tahun dengan nilai temperatur maksimum lebih besar dari nilai persentil ke 90. Berdasarkan Gambar 2 dapat diketahui bahwa indeks TX90p cenderung mengalami peningkatan sejak tahun 2021 hingga 2030 dan didapatkan nilai slope sebesar 1,043. Nilai TX90p tertinggi terjadi pada tahun 2027 sebesar 16,05\% dan terendah pada tahun 2023 sebesar 4,02\%.

Indeks TXn adalah indeks yang mewakili nilai minimum dari temperatur maksimum, sedangkan TXx mewakili nilai maksimum dari temperatur maksimum. Menurut You et al [9], TXn disebut sebagai temperatur terdingin di siang hari (coldest days) dan TXx disebut sebagai temperatur terpanas di siang hari (warmest days). Grafik indeks TXn menunjukkan bahwa nilai minimum dari temperatur maksimum memiliki tren meningkat dengan nilai slope 0,11 sedangkan grafik indeks TXx menunjukkan bahwa nilai maksimum dari temperatur maksimum memiliki tren meningkat dengan nilai slope 0,014 . 
Berdasarkan data beberapa indeks temperatur ekstrim yang meliputi TN10p, TN90p, TX10p dan TX90p, didapatkan gambaran bahwa telah terjadi perubahan pada temperatur ekstrem terkait temperatur minimum dan maksimum. Frekuensi kejadian rata-rata suhu maksimum dan minimum meningkat setiap tahun. Frekuensi kejadian rata-rata temperatur panas dimalam hari dan temperatur panas di siang hari meningkat sementara frekuensi kejadian rata-rata temperatur dingin dimalam hari dan temperatur dingin di siang hari mengalami penurunan. Peningkatan frekuensi kejadian malam hari dengan temperatur yang lebih panas, cenderung berkurangnya frekuensi kejadian temperatur dingin di malam hari, serta semakin meningkatnya jumlah kejadian siang hari yang panas menandakan adanya peningkatan temperatur di permukaan bumi. Secara umum, peningkatan kejadian siang hari yang panas diikuti dengan penurunan kejadian siang hari yang dingin.

Kondisi perawanan juga dapat mempengaruhi nilai temperature maksimum karena awan-awan adalah pemantul radiasi matahari. Oleh karenanya, banyaknya jumlah awan menyebabkan temperatur dingin di siang hari dan temperatur hangat di malam hari (DTR yang rendah).

Perubahan yang terjadi pada temperatur minimum dan maksimum berpengaruh pada nilai Diurnal Temperatur Range (DTR) yang merupakan selisih antara temperatur maksimum di siang hari dan temperatur minimum di malam hari. Nilai DTR cenderung menurun selama periode proyeksi 2021-2030. Penurunan nilai DTR ini terutama disebabkan oleh peningkatan temperatur minimum atau meningkatnya frekuensi temperatur hangat di malam hari. Tren menurun pada DTR merupakan salah satu indikasi adanya perubahan iklim [10].

Berdasarkan indeks R95p yang memiliki kecenderungan meningkat, tetapi CDD dan CWD mengalami penurunan dapat diketahui bahwa selama tahun 2021-2030 jumlah hari dengan hujan $\geq 1 \mathrm{~mm}$ berturut-turut semakin menurun dan jumlah hari tanpa hujan berturut-turut juga semakin menurun. Akan tetapi potensi hujan ekstrim semakin meningkat dan hujan tahunan semakin mengalami peningkatan hal ini memberikan gambaran bahwa potensi terjadinya kekeringan di musim kemarau maupun banjir di musim penghujan semakin meningkat dengan tingginya intensitas hujan. Menurut Aldrian dan Djamil [13], meningkatnya kejadian kekeringan dan cuaca ekstrim di musim penghujan disebabkan oleh penurunan dominansi monsoon yang mendorong perubahan pola tahunan.

Berdasarkan hasil proyeksi untuk tahun 2021-2030 menunjukkan suhu rata-rata, suhu minimum dan suhu maksimum mengalami peningkatan yang cukup signifikan. Kondisi curah hujan juga di proyeksikan meningkat setiap tahunnya dengan meningkatnya curah hujan tahunan dan peningkatan curah hujan ekstrim

\section{Kesimpulan}

Tren temperatur ekstrim menandakan terjadinya peningkatan temperatur dan curah hujan di Stamet Mutiara Palu. Pola presipitasi mengalami perubahan di mana jumlah curah hujan tahunan semakin meningkat dan frekuensi kejadian hujan lebat semakin meningkat selama periode 2021-2030 di Mutiara Palu. Peningkatan frekuensi kejadian cuaca/iklim ekstrim dapat berpotensi terjadinya kekeringan di musim kemarau maupun banjir di musim penghujan seiring meningkat dengan tingginya intensitas hujan. 


\section{DaftarPustaka}

1. C.B. Field, V. Barros, T.F. Stocker, D. Qin, D.J. Dokken, K.L. Ebi, M.D. Mastrandrea, K.J. Mach, G.-K. Plattner, S.K. Allen, M. Tignor, and P.M. Midgley (eds.). Managing the Risks of Extreme Events and Disasters to Advance Climate Change. Cambridge University Press, Cambridge, UK, and New York, NY, USA, 582 pp. 2012.

2. K.E.Trenberth. Changes in precipitation with climate change. Clim Res., Vol. 47, 123-138. 2011.

3. P. Naveau, M. Nogaj, C. Ammann, P. Yiou, D. Cooley, V. Jomelli. Statistical methods for the analysis of climate extremes. C.R. Geoscience, 337, 1013-1022. 2005.

4. M.G. Donat, L.V. Alexander, H. Yang, I. Durre, R. Vose, R.J.H. Dunn, K.M. Willet, E. Aguilar, M. Brunet, J. Caesar, B. Hewitson, C. Jack, A.M.G. Klein Tank, A.C. Kruger, J. Marengo, T.C. Peterson, M. Renom, C.O. Rojas, M. Rusticucci, J. Salinger, A.S. Elrayah, S.S. Sekele, A.K. Srivastava, B. Trewin, C. Villaroel, L.A. Vincent, P. Zhai, X. Zhang, and S. Kitching. Updated analyses of temperatur and precipitation extreme indices since the beginning of the twentieth century: The HadEX2 dataset. J. Geophys. Res.Atmos., v.118:1-16. 2013.

5. A.M.G. Klein Tank, and F.W. Zwiers. Guidelines on Analysis of extremes in a changing climate in support of informed decisions for adaptation. WMO, 2009.

6. T.Z. Insaf, S. Lin, S.C. Sheridan. Climate trends in indices for temperatur and precipitation across New York State, 1948-2008. Air Quality, Atmosphere and Health,Vol.1 No. 1. 2011.

7. Y. Zhang, F. Jiang, W. Wei, M. Liu, W. Wang, L. Bai, X. Li, and S. Wang. Changes in annual maximum number of consecutive dry and wet days during 1961-2008 in Xinjiang, China. Nat. Hazards Earth Syst. Sci., 12,1353-1365. 2012.

8. C.A.C.D. Santos. Trends in Indices for extremes in daily air temperatur over Utah. Revista Brasileira de Meteorologia, v.26, n.1, 19-28. 2011.

9. Q. You, S. Kang, E. Aguilar, N. Pepin, W.A. Flugel, Y. Yan, Y. Xu, Y. Zhang, and J. Huang. Changes in daily climate extremes in China and their connection to the large scale atmospheric circulation during 1961-2003. Clim Dyn. 2010.

10. M. Qu, J. Wan, and X. Hao. Analysis of diurnal air temperatur range change in the continental United States. Weather and Climate Extremes, 4, 86-95. 2014.

11. S. Nugroho, H. Tarigan, E. Sasmita. Tren Curah Hujan Ekstrim di Kota Padang 1970-2008. Megasains, Vol.4 : 25-38. 2009.

12. G.C. Hegerl, F.W. Zwiers, P. Braconnot, N.P. Gillett, Y. Luo, J.A. Marengo Orsini, N. Nicholls, J.E. Penner, and P.A. Stott. Understanding and Attributing Climate Change. In: Climate Change 2007: The Physical Science Basis. Contribution of Working Group I to the Fourth Assessment Report of the Intergovernmental Panel on Climate Change. Cambridge University Press, Cambridge, United Kingdom and New York, NY, USA. 2007.

13. E. Aldrian and Y.S. Djamil. Spatio-temporal climatic change of rainfall in East Java Indonesia. Int. J. Climatol, 28: 435-448. 2008. 